\title{
Climate changes in mangrove forests and salt marshes
}

\author{
Yara Schaeffer-Novelli ${ }^{*}$, Eduardo Juan Soriano-Sierra ${ }^{2}$, Claudia Câmara do Vale ${ }^{3}$,Elaine \\ Bernini ${ }^{4}$, André Scarlate Rovai ${ }^{5}$, Marcelo Antonio Amaro Pinheiro ${ }^{6}$, Anders Jensen Schmidt ${ }^{7}$, \\ Renato de Almeida ${ }^{8}$, Clemente Coelho Júnior ${ }^{9,10}$, Ricardo Palamar Menghini ${ }^{10}$, Diego Igawa \\ Martinez $^{10}$, Guilherme Moraes de Oliveira Abuchahla ${ }^{10}$, Marília Cunha-Lignon ${ }^{10,11}$, Sarah \\ Charlier-Sarubo $^{10}$, Jussara Shirazawa-Freitas ${ }^{10}$, Gilberto Cintrón-Molero ${ }^{10}$
}

\author{
${ }^{1}$ Instituto Oceanográfico da Universidade de São Paulo. \\ (Praça do Oceanográfico, 191 - CEP: 05508-120 - Cidade Universitária, São Paulo (SP) - Brasil) \\ ${ }^{2}$ Núcleo de Estudos do Mar - Universidade Federal de Santa Catarina - Campus Reitor João David Ferreira Lima. \\ (Florianópolis, SC, Brasil. CEP: 88040-900) \\ ${ }^{3}$ Departamento de Geografia, Universidade Federal do Espírito Santo. \\ (Av. Fernando Ferrari, 514 - Goiabeiras | Vitória, ES -Brasil. CEP 29075-910.) \\ ${ }^{4}$ Departamento de Engenharia e Meio Ambiente, Centro de Ciências Aplicadas e Educação, Universidade Federal da Paraíba, Campus IV- Rio Tinto. \\ (Rua da Mangueira, s/n, Rio Tinto/PB - Brasil - CEP - 58297-000) \\ ${ }^{5}$ Universidade Federal de Santa Catarina. Campus Universitário Trindade. \\ (CEP 88040-900 - Florianopolis, SC - Brasil). \\ ${ }^{6}$ Instituto de Biociências, Campus do Litoral Paulista, Universidade Estadual Paulista. \\ (Praça Infante Dom Henrique s/nº Parque Bitaru - CEP 11330-900 - São Vicente - SP - Brasil.) \\ ${ }^{7}$ Instituto de Humanidades, Artes e Ciências Paulo Freire, Universidade Federal do Sul da Bahia. \\ (Praça Joana Angélica, 250, São José, Teixeira de Freitas, BA, Brasil. CEP: 45988-058) \\ ${ }^{8}$ Universidade Federal do Recôncavo da Bahia, CCAAB, Cruz das Almas, BA, Brasil. \\ (Rua Rui Barbosa, 710 - Campus Universitário - CEP 44380-000) \\ ${ }^{9}$ Universidade de Pernambuco, Instituto de Ciências Biológicas. \\ (Av. Agamenon Magalhães, s/n Santo Amaro 50100-130 - Recife, PE - Brasil) \\ ${ }^{10}$ Instituto BiomaBrasil. \\ (Rua Da Aurora, 295, Sala 502 CP 487. Recife - PE - CEP 50050-901) \\ ${ }^{11}$ Universidade Estadual Paulista (UNESP) Campus Registro. \\ (Av. Nelson Brihi Badur, 430 11.900-000 - Registro, SP, Brasil). \\ *Corresponding author: novelliy@usp.br
}

\section{AbSTRACT}

This synthesis is framed within the scope of the Brazilian Benthic Coastal Habitat Monitoring Network (ReBentos WG 4: Mangroves and Salt Marshes), focusing on papers that examine biodiversity-climate interactions as well as human-induced factors including those that decrease systemic resilience. The goal is to assess difficulties related to the detection of climate and early warning signals from monitoring data. We also explored ways to circumvent some of the obstacles identified. Exposure and sensitivity of mangrove and salt marsh species and ecosystems make them extremely vulnerable to environmental impacts and potential indicators of sea level and climate-driven environmental change. However, the interpretation of shifts in mangroves and salt marsh species and systemic attributes must be scrutinized considering local and setting-level energy signature changes; including disturbance regime and local stressors, since these vary widely on a regional scale. The potential for adaptation and survival in response to climate change depends, in addition to the

\section{RESUMO}

Esta é uma síntese enquadrada na Rede de Monitoramento de Habitats Bentônicos Costeiros (ReBentos, GT4: Manguezais e Marismas), embasada em literatura científica que examina interações entre clima e biodiversidade, assim como fatores antrópicos, incluindo aqueles responsáveis pela diminuição da resiliência sistêmica. O objetivo deste trabalho é determinar as dificuldades quanto à detecção de sinais precoces e alertas de mudanças climáticas com dados de monitoramento. No presente trabalho, também foram exploradas formas de contornar os diversos obstáculos identificados. A exposição e a sensitividade de espécies de mangue e de marisma, bem como dos ecossistemas dos quais fazem parte, os tornam extremamente vulneráveis e potenciais indicadores ambientais de mudanças de nível do mar e outras respostas às variações do clima. Entretanto, a interpretação de mudanças em manguezais e marismas e em seus atributos sistêmicos deve ser meticulosa, considerando assinatura energética, regime de distúrbios e pressões ambientais em cada local de estudo. Os potenciais de adaptação e de sobrevivência, em resposta a tais mudanças, dependem da fisiologia de cada espécie e dos processos con-

http://dx.doi.org/10.1590/S1679-875920160919064sp2 
inherent properties of species, on contextual processes at the local, landscape, and regional levels that support resilience. Regardless of stressor type, because of the convergence of social and ecological processes, coastal zones should be targeted for anticipatory action to reduce risks and to integrate these ecosystems into adaptation strategies. Management must be grounded on proactive mitigation and collaborative action based on long-term ecosystem-based studies and well-designed monitoring programs that can 1) provide real-time early warning and 2) close the gap between simple correlations that provide weak inferences and process-based approaches that can yield increasingly reliable attribution and improved levels of anticipation.

Descriptors: Biological indicators, Climate changes, Mangroves, Salt marshes, Sea level rise, Brazil.

\section{INTRODUCTION}

This synthesis is framed within the scope of the Brazilian Benthic Coastal Habitat Monitoring Network (ReBentos WG 4: Mangroves and Salt Marshes) assessment. It presents the results of a survey of the Brazilian and relevant scientific literature regarding mangrove and salt marsh ecosystem biodiversity, focusing on publications that examined species-climate interactions as well as responses to human-induced stressors. A goal of the synthesis is to identify attributes, obstacles and barriers related to the detection of climate signals from monitoring data that could facilitate or hinder the prediction of climate change impacts on species, habitats and coastal landscapes. The assessment attempts to provide a foundation for a more accurate perspective for interpreting change. Along these lines we also explore ways to circumvent some of the difficulties and gaps identified. Most climate changes are expected to be subtle and difficult to detect, but pervasive and highly consequential for coastal species that are tightly coupled to both atmospheric and oceanographic processes. Climate change is expected to accelerate and take place at a rate that may be faster than the speed of species and system adaptation; the identification of vulnerabilities and factors that increase or erode resilience is relevant for conservation planning and management in the context of climate change. Most of these coastal systems are highly productive, capturing large amounts of carbon from the atmosphere while simultaneously local hydrodynamic and geomorphic forces provide effective means for textuais onde reside a resiliência e a capacidade de persistir (em níveis local, de paisagem e regionais). A zona costeira deve ser alvo de medidas antecipatórias para redução de riscos por quaisquer impactos, uma vez que nela há intensa convergência de processos sociais e ecológicos. Os ecossistemas dessa zona devem ser integrados em estratégias de adaptação. O manejo costeiro deve ser embasado em mitigação pró-ativa e colaborativa de longo-termo, sempre com base em estudos ecossistêmicos e em programas de monitoramento que possam 1) prover sistema de alerta precoce; 2) preencher lacunas entre correlações simplistas que proveem inferências fracas, e abordagens baseadas em processos que levem a atribuições mais confiáveis e a melhores níveis de antecipação.

Descritores: Aumento do nível médio relativo do mar, Indicadores biológicos, Manguezal, Marisma, Mudanças climáticas, Brasil.

burial, sequestering carbon in situ, or exporting carbon offshore, where it enters the marine portion of the carbon cycle and storage in deep-water sediments. Thus, these ecosystems offer opportunities for integration into climate adaptation strategies for wetlands which, despite constituting about 5 to $8 \%$ of the terrestrial landscape, sequester and store carbon at the rate of $118 \mathrm{~g} \mathrm{C} / \mathrm{m}^{2} / \mathrm{yr}$ (MITSCH et al., 2012).

Actually only a very small amount of the planet's active carbon resides in the atmosphere, much of it is stored in wetlands. The sequestration process in wetlands is self-organized and self-sustaining as long as substrates remain anaerobic, but has remained underestimated and poorly recognized as an ecosystem service for regulating and stabilizing atmospheric $\mathrm{CO}_{2}$ (AUSTRALIAN GOVERNMENT, 2012). The sequestration capacity of these systems is significant in two critical ways; first, they capture and, second, they provide for the longterm storage of carbon. The destruction, degradation or conversion of these areas can release large amounts of carbon stored since these systems began to occupy transgressive terrains some 6,000 yrs ago (NATIONAL RESEARCH COUNCIL, 1990). This implies that these areas have potential for management to offset industrial and country-level greenhouse-gas emissions and, specifically for Brazil, its Intended Nationally Determined Contribution (INDC) that has been considered inconsistent with limiting warming to below $2^{\circ} \mathrm{C}$ (CLIMATE ACTION TRACKER, 2015). Degradation of coastal wetlands would hinder Brazil from meeting its INDC targets under current policies and would require more stringent emission 
reductions to reach the desired emission reduction goal. Actively protecting these areas for carbon sequestration would make INDC goals easier to reach. Coastal wetlands due to the proximity to the sea are vulnerable to negative climate impacts derived from terrestrial/atmospheric and oceanic climate driven processes (such as increased sea level, storminess and increased wave scouring and coastal erosion) but these losses are exacerbated by poor land use practices. In Brazil these systems are exposed to extremely destructive non-climatic factors, including reclamation for large-scale harbor development and mariculture (shrimp farming), salt harvesting as well as urban sprawl, triggering a coastal squeeze that erodes the capacity for systems to accommodate to rising sea level and to adapt and persist. The ultimate objective of the United Nations Framework Climate Change Convention (1992 UNFCC) is to reduce local emissions in a manner that would allow ecosystems to adapt naturally to climate change (Article 2). In this sense the coastal landscapes we surveyed are indeed "Working Landscapes"; areas to be managed for the protection of human-ecological linkages as well as the sustained delivery of ecological services to the nation and to the global community.

\section{MANGROVES AND SALT MARSHES}

Mangrove and salt marsh species are facultative halophytes with special adaptations to the muddy anaerobic and saline environments they occupy. These are evolutionary responses to the conditions typical of these habitats; such as prolonged waterlogging, anaerobicity and salinity as well as reproductive, dispersal and growth properties that allow rapid colonization of geologically ephemeral substrates. Coastal wetlands grow and decline in response to a number of geomorphic, hydrologic, climatic and human-induced stressors, directly or coincidentally associated with sea-level change (PHILLIPS, 1999). Changes in structural development and in species distribution can generally be correlated with alterations to the tidal and salinity regime or alterations in hydrology (fresh water inputs including seepage and runoff) or alterations in substrate elevation and granulometric composition (SCHAEFFER-NOVELLI et al., 1990, 2002; CUNHA-LIGNON et al., 2011; CHARLIERSARUBO et al., 2015; SORIANO-SIERRA et al., 2015; PINHEIRO; ALMEIDA, 2015). Fresh water-dominated environments inevitably exclude mangrove plants due to the superior adaptation of freshwater plants (glycophytes) to environments where salt is not limiting.

\section{MANGROVES}

Mangroves present discontinuous distribution along the Brazilian coast, covering an area of $9,600 \mathrm{~km}^{2}$ which represents the third largest mangrove area worldwide in a single country (GIRI et al., 2011). According to SPALDING et al. (2010), Brazilian mangroves hold the second place globally, occupying a larger estimated area of $13,000 \mathrm{~km}^{2}$. These values correspond to about $7-8.5 \%$ of the global mangrove area in the world (FAO, 2007; SPALDING et al., 2010; GIRI et al., 2011). In Brazil, mangroves occur from Amapá state $\left(04^{\circ} 20^{\prime} \mathrm{N}\right)$ to Santa Catarina state $\left(28^{\circ} 30^{\prime} \mathrm{S}\right)$ and may present a continuum of different features (facies), depending on the profile of the coastline and the amplitude of the tides (SCHAEFFER-NOVELLI et al., 1990; SOARES et al., 2012). The plant communities of the mangrove ecosystem are unlike any other terrestrial tropical forest, due to the peculiar environmental conditions in which they become established and the large amount of biomass stored in above ground woody structure, below ground root mass and decayed, but stabilized litter accumulations. Mangrove species are often conspicuously banded forming distinct units (or facies) within a mangrove topographic and ecological continuum.

The most seaward unit may appear devoid of plant colonization, similar to a bare mudflat exposed during every neap tide, but this can be deceiving because this surface is biologically and geomorphologicaly acting as a platform that captures allopatric resilience in terms of propagules and materials produced by higher level systems. Mud flats are also biologically and trophically active, supporting microbial primary producers and a rich micro and macrobenthic community. The gently sloping mangrove-covered intertidal ramps are formed by fine sediment accumulations that extend from the lowest to the highest reach of the tide. The size of a tidal ramp varies depending on the terrain slope and the tidal amplitude. This geomorphic structure is dynamic and capable of adjusting itself to sea level change driven by local deposition and erosion processes. Rising sea level provides for uninterrupted landward encroachment as long as physical barriers are not present landward. Mangrove establishment and growth provides a positive feedback that promotes increased deposition while roots stabilize and contribute to elevate the substrate diminishing flooding frequency and increasing deposition. Landward encroachment can compensate for temporary loss of outer fringes following episodic events. The outer portion of 
the tidal ramp is a zone of constant activity in terms of biological and geomorphic processes; sediment deposition and scour, propagule recruitment and short-term change.

Vegetation patterning is driven by the tidal flooding gradient perpendicular to the ramp's long axis and the trajectory and dissipation of the tidal flooding wave front landward. Mangrove stands are dynamic beachheads in a permanent state of aggregation and disaggregation; with the primary control parameter being the tidal energy level and degree of erosional scouring. Mangroves display the attributes of both $\mathrm{r}$ and $\mathrm{K}$ species which allows the rapid colonization and maturation in relatively unstable substrates. The apicum (salt flat), the most landward or elevated feature within a forest is not always present. Its occurrence is associated with less tidal flooding and drier precipitation regimes, being intermittently flooded during spring or the highest and lowest astronomical tides when flooding pumps seawater that becomes subject to intense insolation and evaporation because of the lack of canopy cover. Algal mats prevail here. The macrophytic colonizing vegetation is characterized by herbaceous and shrubby plants. Algal mat assemblages are well adapted to persist under the dominant harsh physical and chemical conditions of the infrequently flooded upper tidal reaches (SCHAEFFER-NOVELLI et al., 2002).

\section{SALt Marsh}

Salt marsh ecosystems occupy tropical, subtropical, and higher latitude coastal zones intermittently flooded with seawater. In Brazil, the most extensive salt marshes are located in the State of Rio Grande do Sul, dominated by Spartina, Juncus, Paspalum, Sesuvium and Bacopa, among others (MARANGONI; COSTA, 2009). Brazil's salt marshes occur all along the sheltered coast, either associated with mangroves or not. The salt marsh flora is adapted to lower temperatures and lower salinities but colonizes similar geomorphic features to mangroves in temperate zones. A sharp ecotone develops when they are found together (CHARLEIR-SARUBO et al., 2015). In transitional climates mangrove-associated salt marshes may form a well-defined fringe of tall grass that facilitates the stranding of propagules that eventually shade and replace the grass species (LEWIS; DUSTAN, 1975; CUNHALIGNON et al., 2009). When salt marshes are not associated with mangroves, the entire intertidal muddy platform may become covered by an extensive monoculture of Spartina. Associated species, having different tolerance to flooding can form distinct bands; although all must be tolerant of salt water, protracted flooding and an anoxic muddy substrate.
Most typical species of salt marshes are facultative halophytes and some species are intolerant to low salinity values (SORIANO-SIERRA et al., 2015). Salt marsh ecosystems consist mainly of perennial or annual herbs often associated with certain species of low shrub (COSTA; DAVY, 1992). These plants are adapted to saline, waterlogged anoxic substrates, including peat. They show xeric leaves with succulent, thick, and dry-type (thin) morphologies. Their rhizomes have thicker anchoring and delicate absorbing roots, which bind unconsolidated sediments (DAWES, 1998). The root system also releases oxygen into the surrounding substrata, modifying the reducing anaerobic rhizosphere (DAWES, 1998).

The root system is one of the most important structural components of mangrove and salt marsh ecosystems, giving rise to thick and fibrous muds, such as those in areas covered by trees of the genus Rhizophora (HESSE, 1961) or grasses of the genus Spartina (SORIANO-SIERRA et al., 2015). Roots bind the sediment stabilizing it. This contributes to substrate and soil building and local surface elevation (WELLS; COLEMAN, 1981; HUXMAN et al., 2010). The process of substrate elevation leads to the formation of depositional terraces that can expand seawards or inland tracking rising sea level (ALONGI et al., 2008; GILMAN et al., 2008).

The physiography of salt marshes is shaped by the local hydrodynamics; the interaction between tidal regime, topography and availability and type of sediments (DAWES, 1998) that eventually leads to the development of particular adaptations; each species has a unique tolerance to salinity and frequency of inundation, which produces a distinct zonation in this otherwise low diversity environment. The floristic diversity found in salt marshes shows latitudinal variation, with lower diversity near the Equator (five species) and higher variety in the temperate zone (twenty species). This diversity is temperature dependent but is affected locally by the presence of brackish water gradients that create zonation and banding patterns as a function of salinity and tidal flood duration (DAWES, 1998). Several salt-tolerant plants develop within these salt marshes, mainly on microtopographic rises in the substrate, such as berms along the channels increasing floristic diversity locally (SORIANO-SIERRA et al., 2015). In tropical settings, biological stressors such as intense competition for space and shading results in less structural development and complexity than in the temperate locations where stressors such as excessively high temperature (water and air) are less intense. 


\section{ASSOCIATED FAUNA}

The importance of environmental conditions in determining distribution and abundance of species is a fundamental tenet of ecology (SHELFORD, 1951). Selforganization is the sorting of species after a disturbance that allows a system to reconfigure and continue functioning in a particular state. When allowed to take place unobstructed, self-organization is a major natural subsidy to management, conservation and sustainability.

Besides birds, a high diversity of associated species occupies the different mangrove facies. Crabs and other invertebrates are found throughout, but can be more abundant in specific places. The environmental gradients in the mangrove and salt marsh ecosystems produce a multiplicity of different microhabitats and patterns of faunal distribution; horizontal zonation, from the edge of the channel to upland areas, vertical zonation, from the canopy to the ground; and axial zonation, from the estuary mouth to its headwater area as well as temporal variations in abundance (e.g., SCHLACHER; WOODRIDGE, 1996; DIELE et al., 2010; DIELE; KOCH, 2010; SCHMIDT et al., 2013).

The tropical mangrove-associated fauna is generally closer to the upper thermal threshold than the temperate salt marsh-associated fauna, which makes them more vulnerable to temperature rise (ALONGI, 2015).

The mangrove crab (Ucides cordatus) recruitment occurs mainly close to the lower limit of the apicum (SCHMIDT et al., 2009), where conditions allow higher aggregation and better development of juveniles (PINHEIRO; ALMEIDA, 2015). Crabs of this species are distributed spatially to form high densities of small individuals in less flooded mangrove features and sandrich sediment areas (DIELE, 2000; SCHMIDT et al., 2009, 2013; PINHEIRO; ALMEIDA, 2015). It is expected that the recruitment zone of $U$. cordatus will shift upland with sea level rise. Human occupation at the apicum (e.g., by urban development, agriculture, shrimp farming or salt harvesting) is expected to block and prevent this natural displacement and reduce the available space for recruitment (SCHMIDT et al., 2013).

The land crab (Cardisoma guanhumi) may also be similarly affected by climate change compounded with direct anthropogenic pressures on its habitat and populations. Studies indicate that recruitment of this species occurs in the apicum, with subsequent migration to the contiguous terrestrial vegetation. An opposite migration occurs when the ovigerous females periodically leave adjacent terrestrial vegetation to migrate through the apicum until larvae are released into mangrove channels and tidal creeks (GIFFORD, 1962). Therefore, both recruitment and reproduction of C. guanhumi depend on the apicum, which tends to shrink when blocked by increasing upland development, and increase sea level. Human occupation of the apicum, as, for example, by shrimp farming and salt pans, hampers both the migration for larval release and the arrival of recruits, leading the local population of $C$. guanhumi to a more vulnerable stage (SCHMIDT et al., 2013).

Both $C$. guanhumi and $U$. cordatus are potential bioindicators of climate change in Brazilian mangrove forests since their spatial distribution is explained by distinct arboreal mangrove facies which would change with sea level rise (NORDHAUS et al., 2006, 2009; SCHMIDT et al., 2008; 2013; WUNDERLICH; PINHEIRO, 2013; PINHEIRO; ALMEIDA, 2015). Due to the complexity of the processes determining the spatial distribution of faunal species, changes in sea level and tidal amplitudes would critically influence mangrove biodiversity.

An increase in the average mean sea level would promote displacement of the zones of occurrence (preferential habitats) of some animal species landward, which is particularly relevant for those species adapted to low flooding frequencies (SCHMIDT et al., 2009).

Variations in sea level can be readily detected based on the vertical displacement of boundaries of sessile invertebrates, such as oysters (VOLETY et al., 2009), that grow attached to the lower structures of mangrove trees, such as aerial roots, prop roots, and branches near the margin of estuarine channels. This correspondence demonstrates the importance of such associated fauna as indicators of sea level variations, as well as indirect forcing influences (BELLA et al., 1992; SKILLETER; WARREN, 2000; SCHAEFFER-NOVELLI et al., 2002; ALFARO, 2010).

Although our exploratory survey of the literature reveals that a fairly extensive body of knowledge regarding mangrove associated fauna exists, naturally this literature has not been framed within the context of climate change. Thus, it is difficult to link population abundances, trends, and expected responses or the identification of specific vulnerabilities, and potential responses to climate change.

COASTAL SETTINGS; MANGROVE AREAS AND SALT MARSHES

Considering the dynamics of the different types of coasts that mangroves occupy and their responses to changes in hydrology or tidal levels mangroves are extremely resilient and robust (THOM, 1967, 1984; 
KJERFVE et al., 2002; JIMENEZ et al., 1985; BLASCO et al., 1996, SCHAEFFER-NOVELLI et al., 2002; SOARES et al., 2012). Mangrove structure is extremely plastic and may exhibit diverse morphologies and multiple stability regimes (sensu SCHEFFER; CARPENTER, 2003), manifested as high or stunted stands, monospecific or mixed forests, and different geofacies.

The landward portion is dynamic in regions where seasonal drought is common, where high insolation prevails and rainfall is not evenly distributed. Hypersaline flats fringe mangrove forests in arid environments and die-offs may be common with many dead trees often left standing on the bare flat, or transient forms (successional stages) found when more moist and benign conditions return. When drought is sustained, as during certain interdecadal periods, these areas (apicum) may expand and appear "bare" and "unproductive" and even non-mangrove when in fact they represent an alternate mangrove ecosystem state when a longer observational period is adopted, and mangroves reoccupy the space. These areas act as "expansion joints" that allow the system to accommodate to decadal or longer oscillations in climate and tidal period, such as the 18.6 tidal cycle (Metonic cycle) and its interaction with meteorological oscillations (such as ENSO and others) This tidal cycle is reported to trigger the movement of fluid muds and promote accretion that forms mud banks (WELLS; COLEMAN, 1981). This oscillation can coincide with ENSO events that impinge on the Brazilian coast, deepening such effects as drought or greater precipitation. On the positive side deeper saline intrusions can also induce interactions between salinity and sulfide that can influence the recruitment and establishment of mangroves. This tidal cycle is present across the world causing the sea level to drop or to rise at an increased rate, so accounting for it and its interaction with interdecadal climate oscillations (this is crucial for the understanding of apicum dynamics, as well as sea level rise detection). Areas of active accretion on the outer edge are characterized by abundant seedlings and juvenile individuals (ALONGI, 2008; ESTRADA et al., 2013; CHARLIER-SARUBO et al., 2015) but the extreme dynamism of this portion of the mangrove belt would make any climate change detection and attribution difficult because change is confounded by increased exposure to short-term atmospheric activity and hydrometeorologcal events such as floods and storminess that drives increased wave and current scouring and tree fall.

According to THOM (1984), mangrove plant species develop in five distinctive geomorphic settings:
(I) river-dominated settings; (II) tide-dominated; (III) wave-dominated; (IV) wave and river-dominated, and (V) drowned valleys. The vegetation in these settings is characterized by individual adaptations, tolerances, and requirements associated with such factors as tidal levels, flooding, salinity or edaphic constraints. Local climatic conditions modify the characteristics of a mangrove forest within each setting, imposing limits on colonization, growth, and development (THOM, 1984; WOODROFFE, 1987; SCHAEFFER-NOVELLI et al., 1990; CINTRONMOLERO; SCHAEFFER-NOVELLI, 1992; VALE, 2010). The most productive and structurally developed mangrove forests (settings I, II and V) are generally those that receive larger subsidies of terrigenous sediment, freshwater supplies and nutrients (THOM, 1984), accumulating large quantities of biomass. Mangrove settings III and IV exhibit intermediate characteristics related to productivity, freshwater inflow, terrigenous sediment, and nutrient input. Thus, structurally welldeveloped mangrove forests are typically found in active geomorphologic areas, subjected to strong depositional inputs of terrigenous sediments and erosion processes that constantly shift sediments (KJERFVE et al., 2002). These types of environments are dynamic mosaics of habitats, including accretion centers where new vegetation establishes itself, areas of stable growth as well as areas showing scouring, loss of forests and eroding or downgrading substrates (SCHAEFFER-NOVELLI et al., 2002).

MANGROVE AND SALT MARSH ECOSYSTEMS' FUNCTIONS AND SERVICES FACING CLIMATE CHANGES

Due to environmental complexity and the time span involved, it is impossible to predict the scope or intensity of changes in the structures that occupy the intertidal zone. Mangrove forests and salt marshes are complex adaptive systems and this entails irreducible uncertainty in their behavior. Uncertainty is irreducible in the sense that it is not decreased by greater knowledge, but must be decreased by prudence, conserving ecological resilience and building propensities for the conservation of the natural processes that sustain self-organization. Maintenance of process is more important than relying on determinism and predictions in conserving living systems (ULANOWICZ, 2009). That is, anticipation and hedging actions are more relevant to planning than prediction when managing complex adaptive systems because of pervasive dynamical instability. 
Ecosystems are always in flux, populations fluctuate naturally and resilience varies through time. The structure of an ecosystem, including its different physiognomies, is controlled largely by inter- and intraspecific competition and selection of propagules (SHELFORD, 1951), with chemical and physical factors showing less direct importance, since the system and its species creates microclimates that dampen or ameliorate stressors. However, ecosystem persistence requires change; it is only through constant probing of its stability domain (sensu HOLLING, 1973) that resilience is built. The metaphor of change that captures this is the adaptive cycle (HOLLING, 1986); after a system attains maturity it begins ageing and the system becomes increasingly vulnerable to internal and external disturbances. When the system's resistance is less than the level of extrinsic force exerted by a perturbation, the system enters a breakdown and release phase, and a new cycle of maturation and breakdown is initiated. This constant renewal activity provides for adaptation to a changing environment. Ecological resilience is the amount of change a system can undergo while retaining its structure and functions. Elasticity or "engineering resilience" is a measure of how long it takes for the system to attain its pre-disturbance state. However, this trajectory depends on ecological memory; e.g. seed banks, saplings and refugia for mobile species, If the disturbance's magnitude is large enough to erase this ecological memory, the system is likely to be tripped to a new configuration or state; low frequency but very intense events (e.g., wind storms, tsunamis, extremes in precipitation and temperature, or prolonged drought) and chronic long-term disturbances (e.g., changes in hydrology produced by dams, embankments, dikes, dredging and spoil deposition) reduce the size of the stability domain and create susceptibility (pre-stressing) for triggering rapid reconfiguration to a different ecosystem. Such transitions may be elicited by low level disturbances (SCHAEFFERNOVELLI et al., 2015).

Coastal wetlands, i.e., mangrove and salt marsh ecosystems, maintain coastal water quality and reduce the severity of infrequent but highly consequential storms, waves and flood damage. Hydrodynamic transport disperses organisms and organic aggregates widely over the whole system (NELLEMANN et al., 2009), this provides for rapid regeneration and renewal after severe disturbances that cause extensive local damage. It also provides for widespread carbon trapping in diverse places and landforms. These areas are important nursery and feeding grounds for many benthic and pelagic species, many of them with high commercial value (ENGLISH et al., 1997) as well as for long-term carbon sequestration. The conservation of coastal zones must be focused on passive measures that enhance robustness, where robustness is related to the duration or longest time span (endurance) of a structure. This is contingent on effective social engagement at all levels. A commitment to endurance requires a multigenerational societal commitment solidly grounded on education.

\section{GLOBAL WARMING}

Changes in temperature, precipitation and extreme events (e.g., hurricanes, storms, etc.), driven by increased atmospheric $\mathrm{CO}_{2}$ concentrations are important agents that increase the impacts related to rising sea levels in wetlands. The responses of mangrove forests and salt marshes to climate change result from the interaction of these factors with local processes and non-climatic stressors that reduce the ecosystems' resilience (ALONGI, 2008; WEBB et al., 2013; UNEP, 2014).

An analysis of climate data of the last four decades indicates a trend of warming atmospheric temperatures all along the Brazilian coast (BERNARDINO et al., 2015). The present scenarios suggest that the increase in air and water surface temperatures may alter the distribution and composition of species, increase or decrease productivity (depending on intensity), increase respiration rates and modify the reproductive phenology of mangrove forests and salt marsh species (FIELD, 1995; CHEESEMAN et al., 1997; SOARES et al., 2012). Increased rates of rainfall may raise silt deposition rates, plant productivity and diversity and alter species distribution (ELLISON, 2000, 2015; KRAUSS et al., 2003; WHELAN et al., 2005).

Studies in the early 1980s indicate that salt marsh community transpiration is raised by thermal stress (HUTCHINGS; SAENGER, 1987). Recent studies indicate that the physiological responses of mangrove forest and salt marsh plants are sigmoidal (manifesting an increase, a plateau and a decline). However, the threshold leading to the decline remains uncertain (ALONGI, 2015).

Higher temperature increases carbon turnover and metabolism in salt marshes and mangrove forests (HUTCHINGS; SAENGER, 1987; ALONGI, 2015). The rise in temperature results in faster growth, reproduction, photosynthesis, respiration, changes in community structure, diversity, and an expansion toward higher latitudinal limits (ALONGI, 2015). 
The ongoing poleward encroachment of mangroves on salt marshes is mostly due to the rise in surface temperature that increases propagule production, dispersal, and establishment (REID; BEAUGRAND, 2012; ALONGI, 2015).

\section{EXTREME WEATHER EVENTS}

Cyclonic storms, and strong convective systems and and other low frequency but highly consequential events are expected to become more frequent due to increased warming of the terrestrial surface. Mesoscale Convective Systems (MCSs) are a complex of thunderstorms that may produce strong squall lines, downbursts and tornados. These events are generated by the warming of the terrestrial surface and have lifespans of several hours (FERREIRA, 2006). They can act over large swathes of terrain and leave significant legacies in terms of localized damage. The scale and intensity of systems like these can result in mass mortalities, erosion, siltation, and decreased plant productivity (JIMENEZ et al., 1985; ALONGI, 2008; YANAGISAWA et al., 2009). Brazil has even experienced unprecedented types of disturbance that had not been previously recorded. On March 2004 a tropical cyclone struck the coast on the border between the states of Santa Catarina and Rio Grande do Sul with winds reaching more than $100 \mathrm{~km} / \mathrm{hr}$. and waves more than $5 \mathrm{~m}$ high near the coast (FERREIRA, 2006). Such phenomena are extremely unusual in the South Atlantic. Previously only two other instances of cyclonic disturbances in the South Atlantic had been recorded, but these never reached the coast, dissipating offshore. Generally, although surface water temperatures may be briefly suitable for cyclonic development, the structure of upper level winds is not conducive to storm development. This unusual event suggests that unprecedented weather phenomena can develop as a result of increased warming and the brief convergence of transient but favorable conditions. Furthermore, it also highlights that the observational record and data coverage has been too limited to "capture" the full spectrum of meteorological phenomena, and that what are considered anomalies might not in fact be so.

Global predictions for the period between 2081-2100 indicate a decrease of between 10 and $40 \%$ in rainfall for northern South America, and an increase of up to $10 \%$ in eastern South America, both relatively to the 1986-2015 reference period (COLLINS et al., 2013). Both areas are predicted to show an increment of up to $0.5 \%$ in salinity (COLLINS et al., 2013).

Mangrove forests in the wet tropics have greater biomass and productivity than do arid zone stands. Trees are taller but less dense (ALONGI, 2015). A rainfall deficit could lead to a loss of mangrove areas due to declines in productivity and the survival of seedlings and changes in interspecific competition (FIELD, 1995; ALONGI, 2008).

The Southeastern coast of Brazil (including the states of Rio de Janeiro, São Paulo, and Paraná) has shown an increase in rainfall recently (BERNARDINO et al., 2015). In general, precipitation is expected to remain the same but not to be uniformly distributed, occurring in short isolated events usually associated with high winds and flooding events associated with intense downpours which are expected to be disruptive to wetlands.

It is expected that structural and functional changes will occur intermittently, driven and accelerated by extreme events such as storms causing alterations in both flooded and in mature forests at the interface with newly submerged lands. In the case of storms, the relatively shallow root system is especially vulnerable to the action of waves and current scour. Thus, the most likely scenario would be sporadic marine transgressions, followed by periods of minor change (SCHAEFFER-NOVELLI et al., 2002) and perhaps change in coastal configuration over periods of decades and progressive inland migration with increased salinization. Severe storms would result in greater impact, with significant destruction of the vegetation cover of salt marshes, where the root system is more vulnerable, as at the outer edge, removing entire clusters of plants, as occurs annually and cyclically as a consequence of winter disturbances.

\section{SEA LEVEL RISE}

Sea level has varied dramatically over the course of the Earth's history with repeated variations exceeding $100 \mathrm{~m}$ from the present sea level. Coastlines colonized by mangroves and salt marshes have been exposed to extensive and virtually continuous disruptions as a result of sea level fluctuations over geological time (WOODROFFE, 1992). Approximately 6,000 yrs ago, marine transgressions slowed down, and the sea level became relatively stable (NATIONAL RESEARCH COUNCIL, 1990).

The melting of the polar caps has been the most significant factor involved in increasing the volume of the oceans; and a coastline exposing such ecosystems to wave energy has reshaped them into a new sea level configuration during this time, though local-level has varied greatly due to site and regional factors (BLOOM; YONEKURA, 1990; WOODROFFE, 1992). Some local effects such as those induced by the estuarine type (e.g., size and configuration) have been associated with oscillations in sea level (see BEERBOWER, 1964). 
In Brazil, studies conducted in the apicum facies have revealed the presence of fossil mangroves, indicating that the sea reached higher levels than at present (SORIANOSIERRA et al., 1998; SAINTILAN; WILLIAMS, 1999; SOARES et al., 2000; SCHAEFFER-NOVELLI et al., 2002; BEHLING et al., 2004; COHEN et al., 2005; STEVENS et al., 2006; SOARES, 2009; HADLICH; UCHA, 2009; FRIESS et al., 2012).

Several temporal scales are involved when examining sea level change; large scale tectonic plate changes are of the order of $10^{6}-10^{9} \mathrm{yrs}$; an intermediate span involves changes related to eustatic variations due to glaciation, which are of the order of $10^{3}-10^{6} \mathrm{yrs}$. (Some tectonic forces also act on this scale). Short-term changes of the order of hours to $10^{3}$ years also take place, and involve astronomical tidal processes and changes related to continuous accommodation to the Holocene transgression. The last few millennia have been a time of high and relatively stable stand after 100 millennia of rapidly changing levels. This brief span of relative stability has shaped the present coastal environments but coastal morphology varies widely even over short distances not only because coastal processes vary in temporal scale, but landforms also evolve at different rates. This condition of stability is expected to change with the advent of greenhouse gas-induced climate change.

Medium-term climatic change will be reflected in sea level change through three processes; 1) the melting of ice in continental ice caps and glaciers; 2) variations in the amount of water stored in lakes and rivers, and 3) steric changes (changes due to thermal expansion). Steric height change has been shown in regional studies to account for seasonal and interannual changes of the order of $100 \mathrm{~mm}$ (NATIONAL RESEARCH COUNCIL, 1990).

In any case the temporal hierarchy of the processes regulating sea level is important in understanding and assessing how mangrove and salt marsh ecosystems will respond in space and time to sea level change. At least five spatio-temporal frames of reference are involved in coastal processes that represent fairly discrete but interacting forcing domains: 1) Coastal Geomorphology, reflecting tectonics and the general character of sedimentation; 2) Regional, reflecting the dominance of particular processes such as that of waves, rivers or tides; 3) Landscape/Physiographic, reflecting specific terrigenous settings and mangrove/ salt marsh habitats; 4) local/stand, reflecting processes at individual landform level, and 5) Site or sub-local, involving greater detail of microtopographical structure within a given landform. This physiographical approach, derived from THOM (1984), provides a flexible way to interpret habitat dynamics on multiple scales. Changes at the higher levels occur at a slower (multi-decadal or more) pace, and act as constraints that buffer change at the lower levels. Climate-induced change triggers instability at the "instantaneous", event scale as well as the "engineering scale" of coastal processes triggering immediate and lasting impacts on human and societal activity (COWEL; THOM, 1994).

High level physiographic and biotic organization provides sustained resistance and resilience. At the lower levels local resilience is expressed as elasticity; manifested in the capacity for regenerating local structure quickly. However, robustness, manifested as persistence, resides in higher level structures and landscape processes that involve the integrity of the whole physiographic unit. In the recent ecological literature the attributes described as "Ascendancy" and "Overhead" (ULANOWICZ, 1990, 1997) seems appropriate to understanding the dynamics of coastal systems. Ascendancy is related to the power or "clout" of a system and its performance. This attribute can be related to size. "Overhead" is the capacity of the system to adapt to the unexpected. It resides in systemic diversity and the redundancy of pathways that can be reconfigured to deal with the unexpected.

Resilience implies not only capacity to respond to expected behavior, but being nimble enough to reorganize and respond to the unprecedented. "Overhead" provides for systemic "breadth" or reliability and ultimate persistence; that is, sustainability. We highlight this because sustainability is often taken to be related to the capacity to bounce back leading to erroneous notions such as "maximum sustained yield" that ignores evolvability, the capacity of the system to react at the genetic level to changing requirements for survival. The mere capacity of a system to return to an earlier state is not sustainability. Ecological resilience is a more useful tool for assessing a system's response to large disturbances and its capacity to persist. Ecological resilience draws attention to multiple scale and cross-scale dynamics. For a more detailed description of these attributes and possible applications in resource management see ULANOWICZ (1997, 2009). Here we suggest these attributes can play a key role in understanding impacts of climate change and in providing insights on how to deal with inevitable environmental change.

The massive human occupation of the tropical and subtropical coastline has been playing a major role in 
the configuration of coastal ecosystems. Although their resilience regarding climate change and changes in sea level has been proven, anthropogenic pressures have pushed them almost to their limit; due to the accelerated speed of change dwindling in size, and the internal degradation of ecosystems. This diminishes their response capacity delaying replacement and restoration of damaged structure and functions to pre-disturbance levels, weakening the capacity to deal with recurrent events.

Effects on mangrove forests and salt marshes may vary from loss in root biomass and in substrate stability to the destruction of above ground structure by undermining and edge scour, causing vegetation coverage to diminish. This process is very similar to that described by SEMENIUK (1980) along the northwest coast of Australia. According to this author, 'sheet' erosion occurs more readily during neap tides, due to the extensive exposure of the tidal flats to desiccation through evaporation, favoring the growth of salt crystals and the disruption of mud aggregates. Later spring tides fills the cavities (e.g., crab burrows) and salt crystals dissolve; loosening the mud, which when it collapses, becomes a dense suspension. The suspended particles are then transported by ebb currents to the sea (VALE, 2010). These effects will be less intense in mesotidal and microtidal environments such as those in Brazil where scouring is reduced and where dense root mats can provide higher levels of substrate stability. However, similar conditions may occur on the Northern Brazil macrotidal coast, where extreme tidal amplitude and seasonal episodes of extreme rainfall-driven flooding trigger severe scouring.

Coastal areas might suffer alteration in sediment budgets, transforming sinks into sources and vice versa. The local and landscape level transport of sediment may be intensified by increases in scouring and erosional rates (MARINS et al., 2003; CUNHA-LIGNON et al., 2011).

Relative sea level curves have been proposed for several sectors of the Brazilian coast. There is, however, no sea level curve with general applicability in view of the fact that each coastal segment has a particular «energy signature» (sensu ODUM, 1969) and is subject to local controls. Relative changes in sea level in a given area are dependent on the interplay between eustasy, local tectonics, and rates of sedimentation as well as endogenous change due to changing geometry.

Due to these local and regional differences in Brazil the landscapes of the middle and upper Holocene include mangrove environments that are both transgressive and regressive. Data suggests a Holocene sea-level maximum between 3.5 and $4.5 \mathrm{~m}$ above the present level. The paleoclimatic records of the Juréia paleolagoon in São Paulo (Brazil) reveal cyclical climate changes correlated with successive transgression-regression episodes in the Holocene (SALLUN et al., 2012). Such anomalies are observed in the Quaternary sediments of paleolagoons (between 7,500 and 9,400 yrs BP) and are correlated with natural events generating high rates of sedimentation $(10 \mathrm{~cm} / \mathrm{yr})$. This suggests that short-term (interdecadal) meteorological events such as those that occur in the North Atlantic, can significantly affect the environment in South America, intensifying summer monsoons (SALLUN et al., 2012).

Mangrove ecosystems have proven to be highly competent in dealing with moderate rates of variation in mean sea level, frequency of flooding, and sediment supply (ALONGI, 2008) if their resilience has not been compromised by other factors such as drought, diversion of hydrologic inputs, and change in tidal regimes (amplitude and frequency). For example, at the delta of the Ganges River a difference in relative sea level of $10-15 \mathrm{~mm} / \mathrm{yr}$, is small compared to the amplitude of the macrotidal regime allowing adaptations in mangrove coverage to occur (WOODROFFE, 1990). However, in a microtidal regime such as that in Bermuda (Caribbean Sea), an increase of only $2.8 \mathrm{~mm} / \mathrm{yr}$ promoted a reduction in sediment deposition rates below the level required for mangrove persistence, resulting in the loss of this ecosystem (ELLISON, 1993, 2015). In contrast, salt marsh ecosystems present high tolerance to flooding, surviving under more than a meter of permanent flooding, as observed in the Conceição Lagoon (Santa Catarina State, Brazil) (SORIANO-SIERRA, 1989).

The ability to recover after a disturbance is an attribute of the environment as a whole and not of a unique plant per se (GRUBB; HOPKINS, 1986; SCHAEFFER-NOVELLI et al., 2005). In a scenario of rapidly rising mean sea level, it is reasonable to expect the disappearance of mangrove forests and salt marshes in exposed littoral zones due to the loss or overtopping of buffering structures (e.g., barriers and similar coastal features that protect from waves and storms) as well as in marginal environments (unsuitable substrates or highly disturbed areas).

The greater development of mangrove forests could be expected in environments characterized by drowned river valleys under maximum sedimentation and large 
tide amplitudes. These areas would serve as reservoirs and reliable sources of mangrove propagules during periods of very rapid changes in the coastline (SCHAEFFERNOVELLI et al., 2002; ALONGI, 2008). The recovery rate (elasticity) of typical mangrove and salt marsh plants depends not only on the pioneering properties of these plant species (as r-strategists), but on the landscapelevel connectivity among sites and dispersion processes, as indicated earlier. This allogenic resilience occurs as a function of the proximity to propagule sources and the existence of appropriate mechanisms for dispersion and transport (LEWIS, 2005).

Plants located in lower tidal elevations are more likely to be impacted. Most salt marshes show particularities in their responses to flooding. With an increasing influence of seawater, essential nutrients may be limited due to ionic effects, as the plants' ability for their uptake is likely to change (DAWES, 1998). Long periods of tidal immersion may result in many negative impacts to the salt marsh plant communities, including: (1) loss of leaves, due to the mechanical effects of tidal currents; (2) death of individuals, due to temperature shock; (3) physiological distress, due to changes in photoperiod, and (4) siltation of leaves, and mortality, due to the blockage of stomata (DAWES, 1998).

On higher ground, above normal tidal incursions, the apicum facies of arid mangrove areas acts as a reservoir of nutrients and supports the developmental stages of some mangrove-associated invertebrates (LACERDA et al., 2001). Prokaryotic cyanophytes are important nitrogen fixers, and nitrogen can be leached or transported by terrestrial drainage, run off, and the ebb tide, thus enriching the adjacent mangrove forest (PALING; MCCOMB, 1994; PALING et al., 2003).

RISING CARBON AND METHANE GASES IN THE ATMOSPHERE

Increased concentration of atmospheric $\mathrm{CO}_{2}$ is expected to promote higher photosynthetic rates and growth in mangrove forests (UNEP, 1994; BALL et al., 1997), but this can be limited by the physiological thresholds imposed by water deficits and higher salinities, caused by increased evapotranspiration that diminishes net production.

ALONGI (2015) reported that the red mangrove (Rhizophora mangle) maturation is stimulated by increased $\mathrm{CO}_{2}$ concentrations during experiments. Growth was enhanced by both high $\mathrm{CO}_{2}$ and low salinity (ALONGI, 2015). Rhizophora mangle is an abundant species in most Brazilian mangrove forests. Another very common species in Brazil, exclusive to the Atlantic Ocean, is the white mangrove (Laguncularia racemosa). Studies show that this species' net primary production, stomatal conductance, and transpiration are compromised by increasing $\mathrm{CO}_{2}$. There was, further, an increase in transpiration efficiency (SNEDAKER; ARAÚJO, 1998). Such metabolic responses might change the composition of mangrove stands, as well as their phenology, completely.

The decline in the ocean's $p H$ has already been observed, due mainly to the higher concentration of greenhouse gases, especially $\mathrm{CO}$ and $\mathrm{CO}_{2}$, in the atmosphere. This is expected to have little or no impact on mangrove forests, due to the daily variation in tidal inundation and soil $\mathrm{pH}$ (ALONGI, 2002). Finally, the disruption of salt marshes and mangrove forests could promote significant impacts on sequestration that in their turn could lead to the release of large amounts of stored carbon into the atmosphere (AUSTRALIAN GOVERNMENT, 2012). Carbon releases include methane gas which has a global warming potential 21 times higher than $\mathrm{CO}_{2}$. The extra methane in the atmosphere contributes greatly to climate change (ARCHER, 2010).

Mangrove forests and salt marshes export particulate matter (e.g., detritus, leaves, twigs, seedlings) that further decomposes in adjacent water bodies (e.g., rivers, estuaries, coastal waters), transforming detritus into organic particulate bacterial/detrital aggregates and dissolved organic matter (HUTCHINGS; SAENGER, 1987; JAFFÉ et al., 2004; DUNN et al., 2008). Inland along the mangrove continuum, in shallow depressions, basin-type mangals occur (LUGO; SNEDAKER, 1974). Much of the litter in these systems is decomposed and exported as dissolved organic matter (DOM) or finer particulate matter, which is of great ecological relevance to adjacent areas (SCHAEFFER-NOVELLI et al., 2002). Besides their role in exporting organic matter, mangrove and salt marsh ecosystems are carbon sinks, storing it in aerial (leaves and wood) and underground structures (SEMENIUK, 1980; NELLEMANN et al., 2009; HUXMAN et al., 2010; BOUILLON, 2011; DONATO et al., 2011).

The role of both mangrove areas and salt marshes is critical as they are biological carbon processors that are coupled to oceanic transport mechanisms via tidal action and currents, which results in carbon dispersal and 
deposition in shelf or deep water reservoirs (BAUER et al., 2013) where carbon can be immobilized for decades, centuries or even millennia (SCHAEFFER-NOVELLI et al., 1990).

\section{FINAL CONSIDERATIONS}

Climate impacts are not manifested as singular pulses and effects on the landscape. Rather, impacts cascade over a complex network of relationships eliciting a spectrum of responses spread over broad spatial and temporal dimensions, and levels of organization. Exposure to disturbances induces dynamism on the annual and decadal scales that is reflected in changes in the populations, biomass, and spatial distribution of the biota. Together, geomorphology, topography, regional and local climate, and disturbances produce heterogeneity creating a tapestry that reflects a complex history of continuous disruption and regeneration. Because of this inherent dynamism species have come

I. In this segment mangrove forest display high levels of aggregate self-organization that reduces chaotic behavior and confers a greater propensity to preserve order amid change. The systems here act as attractors that buffer irregularity and slow down change. Because of its size and vigor this forests entrain the capacity to adapt more successfully insuring relative stability and endurance and ability to cope with short term weather-driven disturbances. Salt marshes are a minor important features of this areas. Coastal marshes are geologically ephemeral and grow and decline in response to geomorphic and climatic events. Complex irregular patterns and local change can be attributed to site-level variations in environmental controls and external stochastic forcing, resulting in highly variable local dynamics within a larger more stable geomorphic unit.

FN

II. This segment is highly dynamic in terms of hydrology and sedimentary activity where fresh water assemblages currently tend to dominate. This dynamism is likely to persist in spite of climate changes although it could be expected that the processes would become increasingly variable. We would expect that this increase variability could become manifested in the predominance of successional facies between mangroves and "aninga" (Montrichardia arborescens) stands. Ephemeral mud banks are often rapidly colonized by salt tolerant grasses and herbaceous species.

III. This segment is characterized by high level of biomass aggregation and system activity that can ensure persistence in spite of increased environmental variability. Sea level rise is expected to favor both inland penetration of mangroves as well as outward expansion. Salt marshes are important features of this areas, but are likely to be more vulnerable to direct or indirect climate change. Currently the major threat to mangroves is unsustainable harvesting of mangrove wood even inside Conservation Units.

IV. This segment is arid, and characterized by short estuaries, and a watershed vulnerable to extreme droughts. Mangrove systems here are spatial limited and more likely to be severely disrupted and temporarily eliminated by stochastic events. Salt marshes are a minor important features of this areas, and may respond in a similar way as mangroves to climate changes. The conjunction of severe environmental constraints (drought, high temperatures) and human-induced stressors (shrimp farming, salt pans and tourist developments) can result in indeterminate outcomes. The still abundant mangrove apicum facies is being threaten by these unsustainable developments.

V. In this segment the mangroves are expected to diminish further due to higher salinities, thermal stress and increasing climatic variability. The coastal hydrology is driven by deep drought events in the interior. Salt marshes are a minor important features of this areas, and may respond in a similar way as mangroves to climate changes. The still abundant mangrove apicum facies is being threaten by unsustainable developments such as human-induced stressors (shrimp farming and tourist developments) reducing resiliency and favoring indeterminate outcomes.

VI. This segment is characterized by extensive large embayments that can act as natural substrates for mangrove and salt marsh occupation. The more significant threats are non-climatic (shrimp farming, tourist developments and the oil production), these reduce resilience to cope with environmental change. Salt marshes are a minor important features of this areas, but are likely to be more vulnerable to direct or indirect climate change.

VII. This segment is also reach in physiographic complexity, which favors mangrove development but is also an area of extreme human occupation in terms of urban and industrial development as well as coastal pollution. In the southern end this segment salt marshes acquire greater dominance increasing the establishment of more complex relationships between both systems, behaving as a higher hierarchical unit; a macro (eco)system.

VIII. Presently this segment is beyond the latitudinal limit of mangrove distribution, however there is evidence of paleomangrove environments. This coastal segment is dominated by extensive elongate brackish coastal lagoons that are partially occupied by extensive marshes.

(FN) Fernando de Noronha Archipelago. Oceanic climate favours an arid climatic regime. There is a single mangrove stand in the main island fed by an intermittent stream that was dammed to build a water reservoir. This stand consists of approximately 40 mature individuals of Laguncularia racemosa in a basin between sand dunes and the shoreline. Sea water enters intermittently through a saddle in the outer marginal dune as storm swash, and perhaps percolates into the basin between storm events.

Figure 1. The assessment of the impact of climate change on mangrove forests and salt marshes along the Brazilian coast. 
to possess adaptations that allowed them to resist and to recover when challenged by natural disturbances if this resilience is not compromised.

Traditional management has been focused on the increase and optimization of economic growth and production, undervaluing or ignoring critical ecological services including self-organization. Climate change demands that the aims of management be the same of those instead as conservation. The importance of pursuing integrated "win-win" and "no-regrets" solutions is more critical than ever to address climate change issues (IPCC, 2012). Sustainable development is inherently a "winwin" "no-regrets" solution when coastal systems with large capacity for carbon sequestration are integrated into climate adaptation strategies.

In a nut shell, the above solutions can be developed through actions that: 1) delay or buffer climate impacts; 2) mitigate impacts through restoration; 3) increase overall resilience and facilitate natural recovery, and 4) reduce non-climate threats and eliminate conversion and reclamation of wetlands.

Based on the classification of SCHAEFFERNOVELLI et al. (1990), we provide a summary of expected effects of the impacts of climate changes on Brazilian mangrove forests and salt marshes (Figure 1).

\section{REFERENCES}

ALFARO, A. C. Effects of mangrove removal on benthic communities and sediment characteristics at Mangawhai Harbour, northern New Zealand. ICES J. Mar. Sci., v. 67, n. 6, p. 1087-1104, 2010.

ALONGI, D. M. Present state and future of the world's mangrove forests. Environ. Conser., v. 1, n. 3, p. 331-349, 2002.

ALONGI, D. M. Mangrove forests: Resilience, protection from tsunamis, and responses to global climate change. Estuar. Coast. Shelf Sci., v. 76, n. 1, p. 1-13, 2008.

ALONGI, D. M. The Impact of Climate Change on Mangrove Forests. Curr. Clim. Change Rep., v. 1, n. 1, p. 30-39, 2015.

ARCHER, D. The global carbon cycle. Princeton Primers Climate. Oxfordshire: Princeton University Press, 2010. 202 p.

AUSTRALIAN GOVERNMENT. Department of the Environment. Issue Paper. The role of wetlands in the carbon cycle. 2012.

BALL, M. C; COCHARANE, M. J.; RAWSON, H. M. Growth and water use of the mangroves Rhizophora apiculata and $R$. stylosa in response to salinity and humidity under ambient and elevated concentrations of atmospheric CO2. Plant. Cell. Environ., v. 20, n. 9, p. 1158-1166, 1997.

BAUER, J. E.; CAI, W. J.; RAYMOND, P. A.; BIANCHI, T. S.; HOPKINSON, C. S.; REGNIER, P. A. The changing carbon cycle of the coastal ocean. Nature, v. 504, n. 7478, p. 61-70, 2013.
BEERBOWER, J. R. Cyclothems and cyclic depositional mechanisms in alluvial plain sedimentation. In: MERRIAM, D. F. (Ed.). Symposium on cyclic sedimentation. Lawrence: Kansas Geological Survey, Bulletin, 1964. p. 31-42.

BEHLING, H.; COHEN, M. C. L.; LARA, R. J. Late Holocene mangrove dynamics of Marajó Island in Amazonia, northern Brazil. Veg. Hist. Archeobot., v. 13, p. 73-80, 2004.

BELLA, D.; LI, H.; JACOBS, R. Ecological indicators of global climate change. Proceedings of a U.S. Fish and Wildlife Service Global Climate Change Workshop. Washington: (Oregon State University, Corvallis, 13-15 November 1990), 1992. $50 \mathrm{p}$.

BERNARDINO, A. F.; NETTO, S. A.; PAGLIOSA, P. R.; BARROS, F.; CHRISTOFOLETTI, R. A.; ROSA FILHO, J. S.; COLLING, A.; LANA, P. C. Predicting ecological changes on benthic estuarine assemblages through decadal climate trends along Brazilian Marine Ecoregions. Estuar. Coast. Shelf Sci., v. 166, p. 74-82, 2015.

BLASCO, F.; SAENGER, P.; JANODET, E. Mangrove as indicators of coastal change. Catena, v. 27, n. $3 / 4$, p. 167178, 1996.

BLOOM, A. I.; YONEKURA, N. Graphic analysis of dislocated Quaternary shorelines. In: National Research Council, Sea-level change. In: SELIGER, U. (Ed.). Coastal Plant Communities of Latin America. New York: Academic Press, 1990. p. 104-115.

BOUILLON, S. Carbon cycle: Storage beneath mangroves. Nat. Geosci., v. 4, n. 5, p. 282-283, 2011.

CHARLIER-SARUBO, S.; CUNHA-LIGNON, M.; SCHAEFFER-NOVELLI, Y. Protocolo de coleta de dados e monitoramento dos ecótonos entre manguezal e marisma e entre manguezal e vegetação de restinga. In: TURRA, A.; DENADAI, M. R. (Orgs.). Protocolos de campo para o monitoramento de habitats bentônicos costeiros. Rede de Monitoramento de Habitats Bentônicos Costeiros. São Paulo: ReBentos, 2015. p. 104-111.

CHEESEMAN, J. M. et al. Photosynthesis and photoprotection in mangroves under field conditions. Plant Cell and Environment, v. 20, p. 579-588, 1997.

CINTRÓN-MOLERO, G.; SCHAEFFER-NOVELLI, Y. Ecology and management of New World mangroves. In: SEELIGER, U. (Ed.). Coastal Plant Communities of Latin America. New York: Academic Press, 1992. p. 233-258.

CLIMATE ACTION TRACKER. Tracking INDCs 2015. Brazil assessment. Brazil's INDC. Available: <www. climateactiontracker.org $>$ Accessed: 28 September 2015.

COHEN, M. C. L.; BEHLING, H.; LARA, R. J. Amazonian mangrove dynamics during the last millennium: The relative sea-level and the Little Ice Age. Rev. Paleo. Palin., v. 136, p. 93-108, 2005.

COLLINS, M.; KNUTTI, R.; ARBLASTER, J.; DUFRESNE. J. L.; FICHEFET, T.; FRIEDLINGSTEIN, P.; GAO, X.; GUTOWSKI, W. J.; JOHNS, T.; KRINNER, G.; SHONGWE, M.; TEBALDI, C.; WEAVER, A. J.; WEHNER, M. Long-term climate change: projections, commitments and irreversibility. In: STOCKER, T. F.; QIN, D.; PLATTNER, G. K.; TIGNOR, M.; ALLEN, S. K.; BOSCHUNG, J.; NAUELS, A.; XIA, Y.; BEX, V.; MIDGLEY, P. M. (Eds.). Climate change 2013: the physical basis, contribution of working group I to the fifth assessment report of the Intergovernmental Panel on Climate Change. Cambridge: Cambridge University Press, 2013. p. 1029-1136. 
COSTA, C. S. B.; DAVY, A. J. Coastal Saltmarsh Communities of Latin America. In: SEELIGER, U. (Ed.). Coastal Communities of Latin America. New York: Academic Press, p. 179-199, 1992.

COWEL, P. J.; THOM, B. G. Morphodynamics of coastal evolution. In: CARTER, R. W. G.; WOODROFFE, C. D. (Eds.). Coastal Evolution Late Quaternary Shoreline Morphodynamics. London: Cambridge University Press, 1994, p. 33-86.

CUNHA-LIGNON, M.; COELHO- JR., C.; ALMEIDA, R.; MENGHINI, R.; CORREA, F.; SCHAEFFER-NOVELLI, Y.; CINTRON-MOLERO, G.; DAHDOUH-GUEBAS, F. Mangrove Forests and Sedimentary Processes on the South of Coast of Sao Paulo State (Brazil). J. Coast. Res., SI, v. 56, p. 405-409, 2009.

CUNHA-LIGNON, M.; KAMPEL, M.; MENGHINI, R. P.; SCHAEFFER-NOVELLI, Y.; CINTRÓN, G.; DAHDOUHGUEBAS, F. Mangrove forests submitted to depositional processes and salinity variation investigated using satellite images and vegetation structure surveys. J. Coastal Res., v. 64 , p. $344-348,2011$

DAWES, C. J. Marine Botany. New York: John Wiley and Sons, 1998. $480 \mathrm{p}$.

DIELE, K.; KOCH, V. Comparative Population Dynamics and Life Histories of North Brazilian Mangrove Crabs, Genera Uca and Ucides. In: SAINT-PAUL, U.; SCHNEIDER, H. (Eds.). Mangrove Dynamics and Management in North Brazil, Ecological Studies 211. Springer-Verlag, Germany, p. 275-283, 2010. chapter 18 .

DIELE, K. Life history and population structure of the exploited mangrove crab Ucidescordatus (Linnaeus, 1763) (Decapoda: Brachyura) in the Caeté Estuary, North Brazil. Bremen: Center for Tropical Marine Ecology, Contribution 9, ZMT Bremen, 2000. 103 p.

DIELE, K.; KOCH, V.; ABRUNHOSA, F. A.; LIMA, J. de F.; SIMITH, D. de J. de B. The Brachyuran crab community of the Caeté Estuary, North Brazil: species richness, zonation and abundance. In: SAINT-PAUL, U.; SCHNEIDER, H. (Ed.). Mangrove dynamics and management in North Brazil. Ecol. Studies, 211, Chap. 16, p. 251-264, 2010

DONATO, D. C.; KAUFFMAN, J. B.; MURDIYARSO, D.; KURNIANTO, S.; STIDHAM, M.; KANNINEN, M. Mangroves among the most carbon-rich forests in the tropics. Nat. Geosci., v. 4, p. 293-297, 2011.

DUNN, R. J. K.; WELSH, D. T.; TEASDALE, P. R.; LEE, S. Y.; LEMCKERT, C. J.; MEZIANE, T. Investigating the distribution and sources of organic matter in surface sediment of Coombabah Lake (Australia) using elemental, isotopic and fatty acid biomarkers. Continent. Shelf Res., v. 28, p. 2535-2549, 2008.

ELLISON, A. M. Mangrove restoration: Do we know enough? Restor Ecol., v. 8, n. 3, p. 219-229, 2000.

ELLISON, J. C. Mangrove retreat with rising sea-level, Bermuda. Estuar. Coast. Shelf Sci., v. 37, p. 75-87, 1993.

ELLISON, J. C. Vulnerability assessment of mangroves to climate change and sea-level rise impacts. Wetlands Ecol. Manag., v. 23, n. 2, p. 115-137, 2015.

ENGLISH, S.; WILKINSON, C.; BAKER, V. Survey manual for tropical marine resources. 2nd ed. Townsville: Australian Institute of Marine Science, 1997. 390 p.

ESTRADA, G. C. D.; SOARES, M. L. G.; CHAVES, F. O.; CAVALCANTI, V. F. Analysis of the structural variability of mangrove forests through the physiographic types approach. Aquat. Bot., v. 111, p. 135-143, 2013.
FAO (Food and Agriculture Organization of the United Nations). The world's mangroves 1980-2005. A thematic study prepared in the framework of the Global Forest Resources Assessment 2005. Rome: Food and Agriculture Organization of the United Nations, 2007. $77 \mathrm{p}$.

FERREIRA, A. G. Meteorologia prática. São Paulo: Oficina de Textos, 2006. 188 p.

FIELD, C. D. Impact of expected climate change on mangroves. Hydrobiologia, v. 295, p. 75-81, 1995.

FRIESS, D. A.; KRAUSS, K. W.; HORSTMAN, E. M.; BALKE, T.; BOUMA, T. J.; GALLI, D.; WEBB, E. L. Are all intertidal wetlands naturally created equal? Bottlenecks, thresholds and knowledge gaps to mangrove and saltmarsh ecosystems. Biol. Rev. Camb. Philos. Soc., v. 87, n. 2, p. 346-366, 2012.

GIFFORD, C. A. Some observations on the general biology of the land crab, Cardisoma guanhumi (Latreille), in South Florida. Biol. Bull., v. 123, n. 1, p. 207-223, 1962.

GILMAN, E. L.; ELLISON, J.; DUKE, N. C.; FIELD, C. Threats to mangroves from climate change and adaptation options: A review. Aquat. Biol., v. 89, n. 2, p. 237-250, 2008.

GIRI, C. E.; OCHIENG, E.; TIESZEN, L.; ZHU, Z.; SINGH, A.; LOVELAND, T.; MASEK, J.; DUKE, N. Status and distribution of mangrove forests of the world using earth observation satellite data. Glob. Ecol. Biogeogr., v. 20, n. 1, p.154-159, 2011.

GRUBB, P. J.; HOPKINS, A. J. M. Resilience at the level of the plant community. In: DELL, B.; HOPKINS, A. J. M.; LAMONT, B. B. (Eds.). Resilience in Mediterranean-type ecosystems. Dordrecht: Dr. Junk, 1986.

HADLICH, G. M.; UCHA, J. M. Apicuns: aspectos gerais, evolução recente e mudanças climáticas globais. Rev. Bras. Geomorf., v. 10, n. 2, p. 13-20, 2009.

HESSE, P. R. Some differences between the soils of Rhizophora and Avicennia mangrove swamps in Sierra Leone. Plant. Soil., v. 14, p. 335-346, 1961.

HOLLING, C. S. Resilience and stability of ecological systems. Annu. Rev. Ecol. Evol. Syst., v. 4, p. 1-23. 1973.

HOLLING, C. S. Engineering resilience vs. ecological resilience. In: SCHULZE, P. C. (Ed.). Engineering within ecological constraints. Washington: National Academy Press, 1986. p. 31-43.

HUTCHINGS, P. A.; SAENGER, P. Ecology of Mangroves. St Lucia: University of Queensland Press, 1987. 388 p.

HUXMAN, M.; KUMARA, M. P.; JAYATISSA, L. P.; KRAUSS, K. W.; KAIRO, J.; LANGAT, J.; MENCUCCINI, M.; SKOV, M. W.; KIRUI, B. Intra- and interspecific facilitation in mangrove may increase resilience to climate change threats. Philos. Trans R. Soc. Lond. B. Biol. Sci., v. 365, p. 2127-2135, 2010.

IPCC - INTERGOVERNMENTAL PANEL ON CLIMATE CHANGE, Managing the risks of extreme events and disasters to advance climate change adaptation. In: FIELD, C. B.; BARROS, V.; STOCKER, T. F.; QIN, D.; DOKKEN, D. J.; EBI, K. L.; MASTRANDREA, M. D.; MACH, K. J.; PLATTNER, G. K.; ALLEN, S. K.; TIGNOR, M.; MIDGLEY, P. M. (Eds.) A special report of Working Group I and II of the IPCC. New York: Cambridge University Press, 2012. $582 \mathrm{p}$.

JAFFÉ, R.; BOYER, J. M.; LU, X.; MAIE, N.; YANG, C.; SCULLY, N. M.; MOCK, S. Source characterization of dissolved organic matter in a subtropical mangrovedominated estuary by fluorescence analysis. Mar. Chem., v. 84 , p. 195-210, 2004. 
JIMENEZ, J. A.; LUGO, A. E.; CINTRÓN, G. Tree mortality in mangrove forests. Biotropica, v. 17, n. 3, p. 177-185, 1985.

KJERFVE, B.; PERILLO, G. M. E.; GARDNER, L. R.; RINE, J. M.; DIAS, G. T. M.; MOCHEL, F. R. Morphodynamics of muddy environments along the Atlantic coasts of North and South America. In: HEALY, T.; WANG, Y.; HEALY, J. A. (Eds.). Muddy Coasts of the World: Processes, Deposits and Function. Amsterdam: Elsevier, 2002. p. 479-532.

KRAUSS, K. W.; ALLEN, J. A.; CAHOON, D. R. Differential rates of vertical accretion and elevation change among aerial root types in Micronesian mangrove forests. Estuar. Coast. Shelf Sci., v. 56, p. 251-259, 2003.

LACERDA, L. D.; SILVA, L. F. F.; MARINS, R. V.; MOUNIER, S.; PARAQUETTI, H. H. M.; BENAIM, J. Dissolved mercury concentrations and reactivity in mangrove waters from Itacurussá Experimental Forest, Sepetiba Bay, SE Brazil. Wetl. Ecol. Manag., v. 9, n. 4, p. 323-331, 2001.

LEWIS, R. R.; DUSTAN, F. M. Possible role of Spartina alterniflora Loisel in establishment of mangroves in Florida. In: LEWIS, R. R. (Ed.). Proceedings of the Second Annual Conference on Restoration of Coastal Vegetation in Florida, 1975. p. 82-100, 1975.

LEWIS, R. R. Ecological engineering for successful management and restoration of mangrove forests. Ecol. Eng., v. 24, p. 403418,2005

LUGO, A. E.; SNEDAKER, S. C. The ecology of mangroves. Annu. Rev. Ecol. Evol. Syst., v. 5, p. 39-64, 1974.

LUGO, A. E. Mangrove ecosystems: successional or steady state? Biotropica, v. 12, n. 2, p. 65-72, 1980.

MARANGONI, J. C.; COSTA, C. S. B. Diagnóstico ambiental das marismas no estuário da Lagoa dos Patos - RS. Atlântica, Rio Grande, v. 31, n. 1, p. 85-98, 2009.

MARINS, R. V.; LACERDA, L. D.; ABREU, I. M.; DIAS, F. J. S. Efeitos da açudagem no rio Jaguaribe. Ciência Hoje, v. 33, p. 66-70, 2003.

MITSCH, W. J.; BERNAL, B.; NAHLIK, A.; MANDER, Ü.; ZHANG, L.; ANDERSON, C. J.; JØRGESEN, S. E.; BRIX, H. Wetlands, carbon and climate change. Landsc. Ecol., v. 28, n. 4, p. 583-597, 2012.

NATIONAL RESEARCH COUNCIL. Sea-level change. Washington: National Academy Press, 1990.

NELLEMANN, C.; CORCORAN E.; DUARTE, C. M; VALDÉS, L.; DE YOUNG, C.; FONSECA, L.; GRIMSDITCH, G. Blue carbon. A Rapid Response Assessment. Grinda: United Nations Environment Programme, GRID, 2009. 80 p.

NORDHAUS, I.; DIELE, K.; WOLFF, M. Activity patterns, feeding and burrowing behaviour of the crab Ucides cordatus (Ucididae) in a high intertidal mangrove forest in North Brazil. J. Exp. Mar. Biol. Ecol., v. 374, p. 104-112, 2009.

NORDHAUS, I.; WOLFF, M.; DIELE, K. Litter processing and population food intake of the mangrove crab Ucides cordatus in a high intertidal forest in northern Brazil. Estuar. Coast. Shelf Sci., v. 67, p. 239-250, 2006.

PALING, E. I.; MCCOMB, A. J. Cyanobacterial Mats: A possible nitrogen source for Arid-Coast Mangroves. Inter. J. Ecol. Envir. Sci., v. 20, p. 47-54, 1994

PALING, E. I.; HUMPHREYS, G.; MCCARDLE, I. The effect of a harbour development on mangroves in northwestern Australia. Wetl. Ecol. Manag., v. 54, p. 281-290, 2003.

PHILLIPS, J. D. Earth surface systems: complexity, order and scale. Oxford: Blackwell Publishers, 1999. 180 p.
PINHEIRO, M. A. A.; ALMEIDA, R. Monitoramento da densidade e da estrutura populacional do caranguejo-uçá, Ucides cordatus (Linnaeus, 1763) (Brachyura: Ucididae). In: TURRA, A.; DENADAI, M. R. (Orgs.). Protocolos de campo para o monitoramento de habitats bentônicos costeiros. Rede de Monitoramento de Habitats Bentônicos Costeiros. São Paulo: ReBentos, 2015. p. 118-129.

REID, P. C.; BEAUGRAND, G. Global synchrony of an accelerating rise in sea surface temperature. J. Mar. Biol. Assoc. U. K., v. 92, n. 7, p. 1435-1450, 2012.

SAINTILAN, N.; WILLIAMS, R. J. Mangrove transgression into saltmarsh environments in eastern Australia. Glob. Ecol. Biogeogr., v. 8, p. 117-124, 1999.

SALLUN, A. E. M.; SALLUN FILHO, W.; SUGUIO, K.; BABINSKI, M.; GIOIA, S. M. L.; HARLOW, B. A.; DULEBA, W.; OLIVEIRA, P. O.; WEBER, M. J. G. C. Z.; CHRISTOFOLETTI, S. R.; SANTOS, C.; MEDEIROS, V.; SILVA, J. B.; SANTIAGO-HUSSEIN, M. C.; FERNANDES, R. S. Geochemical evidence of the $8.2 \mathrm{ka}$ event and other Holocene environmental changes recorded in paleolagoon sediments, southeastern Brazil. Quat. Res., v. 77, n. 1, p. 3143, 2012

SCHAEFFER-NOVELLI, Y.; CINTRÔN-MOLERO, G.; ADAIME, R. R.; CAMARGO, T. M. Variability of the mangrove ecosystem along the Braz. Coast. Estuaries, v. 13, n. 2, p. 204-218, 1990.

SCHAEFFER-NOVELLI， Y.; CINTRÓN-MOLERO， G.; SOARES, M. L. G. Mangroves as indicators of sea level change in the muddy coasts of the world. In: HEALY, T.; WANG, Y.; HEALY, J. A. (Eds.). Muddy Coasts of the World: Processes, Deposits and Function. Muddy Coasts of the World: Processes, Deposits and Function. Amsterdam: Elsevier, 2002, p. 245-262.

SCHAEFFER-NOVELLI, Y.; MOLERO, G. C.; LIGNON, M. C.; COELHO-JÚNIOR, R. C. A conceptual hierarchical framework for marine coastal management and conservation: a "JanusLike” approach. J. Coastal Res., v. 42, p. 191-197, 2005.

SCHAEFFER-NOVELLI, Y.; VALE, C.C.; CINTRÓN, G. Protocolo de monitoramento do ecossistema manguezal - estrutura e características funcionais - como indicador de mudanças climáticas. In: TURRA, A.; DENADAI, M. R. (Orgs.). Protocolos de campo para o monitoramento de habitats bentônicos costeiros - Rede de Monitoramento de Habitats Bentônicos Costeiros. São Paulo: ReBentos, 2015. p. 59-76, 2015.

SCHEFFER, M.; CARPENTER, S. R. Catastrophic regime shifts in ecosystems: linking theory to observation. Trends Ecol. Evol., v. 18, n. 12, p. 648-656, 2003.

SHELFORD, V. E. Fluctuations of forest animal populations in east central Illinois. Ecol. Monogr., v. 21, n. 2, p.183-214. 1951.

SCHLACHER, T. A.; WOOLDRIDGE, T. H. Axial zonation patterns of subtidal macrozoobenthos in the Gantoos estuary, South Africa. Estuaries, v. 19, n. 3, p. 680-696, 1996.

SCHMIDT, A. J.; BEMVENUTI, C. E.; DIELE, K. Effects of geophysical cycles on the rhythm of mass mate searching of a harvested mangrove crab. Anim. Behav., v. 84, n. 2, p. 333340, 2012.

SCHMIDT, A. J.; BEMVENUTI, C. E.; DIELE, K. Sobre a definição da zona de apicum e sua importância ecológica para populações de caranguejo-uçá Ucides cordatus (Linnaeus, 1763). Bol. Técn. Cient. CEPENE, v. 19, n. 1, p. 9-25, 2013. 
SCHMIDT, A. J.; OLIVEIRA, M. A.; SOUZA, E. P.; MAY, M.; ARAÚJO, S. M. B. Relação entre abertura de galeria e comprimento de cefalotórax do caranguejo-uçá, Ucides cordatus (Linnaeus, 1763) (Crustacea-Decapoda-Brachyura). Bol. Técn. Cient. CEPENE, v. 16, n. 1, p. 51-58, 2008.

SCHMIDT, A. J.; OLIVEIRA, M. A.; SOUZA, E. P.; MAY, M.; ARAÚJO, S. M. B. Estudo comparativo da dinâmica populacional de caranguejo-uçá, Ucides cordatus (Linnaeus, 1763) (Crustacea-Decapoda-Brachyura), em áreas afetadas e não afetadas por uma mortalidade em massa no Sul da Bahia, Brasil. Bol. Técn. Cient. CEPENE, v. 17, n. 1, p. 41-64, 2009.

SEMENIUK, V. Mangrove zonation along en eroding coastline in King Sound North-Western Australia. J. Ecol., v. 68, n. 3, p. $789-912,1980$.

SKILLETER, G. A.; WARREN, S. Effects of habitat modification in mangroves on the structure of mollusk and crab assemblages. J. Exp. Mar. Biol. Ecol., v. 244, n. 1, p. 107$129,2000$.

SNEDAKER, S. C.; ARAÚJO, R. J. Stomatal conductance and gas exchange in four species of Caribbean mangroves exposed to ambient and increased $\mathrm{CO}_{2}$. Mar. Freshw. Res., v. 49, n. 4, p. 325-327, 1998.

SOARES, M. L. G. A conceptual model for the responses of mangrove forests to sea level rise. J. Coastal Res., v. 56, p. 267-271, 2009.

SOARES, M. L. G.; ESTRADA, G. C. D.; FERNANDEZ, V.; TOGNELLA, M. M. P. Southern limit of the Western South Atlantic mangroves: Assessment of the potential effects of global warming from a biogeographical perspective. J. Coastal Res., v. 101, n. 10, p. 44-53, 2012.

SOARES, M. L. G.; SCHAEFFER-NOVELLI, Y.; CINTRONMOLERO, G. The use of mangroves as indicators of sealevel changes. In: International wetland symposium, 6 . International association of ecology. Canada: Millennium wetland event, Quebec, 2000. 213 p.

SORIANO-SIERRA, E. J. Ecossistemas de marismas. II. A fitocenosis. ACIESP, v. 71, p. 142-149, 1989.

SORIANO-SIERRA, E. J.; LEDO, B. S.; QUEIROZ, R. U. Ecological costs of urban expansion in a mangrove ecosystem. A case study. Ecologia e Gerenciamento do Manguezal de Itacorubi. Fepema, v. 3, p. 369-378, 1998.

SORIANO-SIERRA, E. J.; SCHAEFFER-NOVELLI, Y.; ROVAI, A. S.; BERNINI, E.; ABUCHAHLA, G. M. O. Protocolo mínimo para monitoramento da estrutura de pradarias de marismas como indicadora de mudanças climáticas. In: TURRA, A.; DENADAI, M. R. (Orgs.). Protocolos de campo para o monitoramento de habitats bentônicos costeiros. Rede de Monitoramento de Habitats Bentônicos Costeiros. São Paulo: ReBentos, 2015. p. 112-117

SPALDING, M.; KAINUMA, M.; COLLINS, L. World Atlas of Mangrove. London: Earthscan Publications, 2010. 336 p.

STEVENS, P. W.; FOX, S. L.; MONTAGUE, C. L. The interplay between mangroves and saltmarshes at the transition between temperate and subtropical climate in Florida. Wetl. Ecol. Manag., v. 14, n. 5, p. 435-444, 2006.

THOM, B. G. Mangrove ecology and deltaic geomorphology, Tabasco, México. J. Ecol., v. 55, n. 2, p. 301-343, 1967.

THOM, B. G. Coastal landforms and geomorphic processes. In: SNEDAKER, S. C.; SNEDAKER, J. G. (Eds.). The mangrove ecosystem: research methods. Paris: UNESCO, 1984. p. 3-17.
UNITED NATIONS ENVIRONMENT PROGRAMME (UNEP). Assessment and monitoring of climatic change impacts on mangrove ecosystems. UNEP Regional Seas Reports and Studies No. 154. Nairobi: UNEP, 1994. 62 p.

UNITED NATIONS ENVIRONMENT PROGRAMME (UNEP). The Importance of Mangroves to People: A Call to Action. In: BOCHOVE, J. VAN; SULLIVAN, E.; NAKAMURA, T. (Eds.). United Nations Environment Programme. Cambridge: World Conservation Monitoring Centre, 2014. 128 p.

ULANOWICZ, R. E. Aristotelean causalities in ecosystem development. Oikos, 57:42-48, 1990.

ULANOWICZ, R. E. Ecology the Ascendent Perspective. Columbia University Press, New York, 1997. 201 p.

ULANOWICZ, R. E. A third window: natural life beyond Newton and Darwin. Pennsylvania, Templeton Foundation Press, 2009. $196 \mathrm{p}$.

UNITED NATIONS. United Nations Framework Convention on Climate Change. FCCC/INFORMAL/84 - GE.05-62220 (E) 200705, 1992. $25 \mathrm{p}$.

VALE, C. C. Correlação entre os processos erosivos e sedimentares e o comportamento das espécies vegetais dos manguezais da foz do rio São Mateus, litoral norte do Estado do Espírito Santo. GEOUSP: Espaço e Tempo, v. 27, p. 113134,2010 .

VOLETY, A. K.; SAVARESE, M; TOLLEY, S. G.; ARNOLD, W. S.; SIME, P.; GOODMAN, P.; CHAMBERLAIN, R. H.; DOERING, P. H. Eastern oysters (Crassostrea virginica) as an indicator for restoration of Everglades Ecosystems. Ecol. Indic., v. 9S, p. S120-S136, 2009.

WEBB, E. L.; FRIESS, D. A.; KRAUSS, K. W.; CAHOON, D. R.; GUNTENSPERGEN, G. R.; PHELPS, J. A global standard for monitoring coastal wetland vulnerability to accelerated sea-level rise. Nat. Clim. Chang., v. 3, n. 5, p. 458-465, 2013.

WELLS, J. T.; COLEMAN, J. M. Periodic mudflat progradation, northeastern coast of South America: a hypothesis. J. Sediment. Petrol., v. 51, p. 1069-1075, 1981.

WHELAN, K. R. T.; SMITH, T. J.; CAHOON, D. R.; LYNCH, J. C.; ANDERSON, G. H. Groundwater control of mangrove surface elevation: shrink and swell varies with soil depth. Estuaries, v. 28, n. 6, p. 833-843, 2005.

WOODROFFE, C. D. Pacific island mangroves: distribution and environmental settings. Pacif. Sci., v. 41, n. 1-4, p. 166-185, 1987.

WOODROFFE, C. D. The impact of sea level rise on mangroves shorelines. Prog. Phys. Geogr., v. 14, n. 4, p. 483-520, 1990.

WOODROFFE, C. D. Mangrove sediments and geomorphology. In: ROBERTSON, A. L.; ALONGI, D. M. (Eds.). Coastal and Estuarine Studies. Washington: American Geophysical Union, 1992. p. 7-41.

WUNDERLICH, A. C.; PINHEIRO, M. A. A. Mangrove habitat partitioning by Ucides cordatus (Ucididae): effects of the degree of tidal flooding and tree-species composition during its life cycle. Helgol. Mar. Res., v. 67, n. 2, p. 279- 289, 2013.

YANAGISAWA, H.; KOSHIMURA S.; GOTO K.; MIYAGI, T.; IMAMURA, F.; RUANGRASSAMEE, A.; TANAVUD, C. The reduction effects of mangrove forest on a tsunami based on field surveys at Pakarang Cape, Thailand, and numerical analysis. Estuar. Coast. Shelf Sci., v. 81, n. 1, p. 27-37, 2009. 